\title{
Variabel-Variabel yang Mempengaruhi Intensitas Merokok Remaja Pria di Indonesia Tahun 2017
}

\author{
Vivy Maharani ${ }^{1 *}$, Titik Harsanti ${ }^{2}$ \\ ${ }^{1,2}$ Politeknik Statistika STIS \\ Jalan Otto Iskandar Dinata 64C Jakarta Timur \\ E-mail:211710045@stis.ac.id
}

(Variables that affect the smoking intensity of male adolescents in Indonesia in 2017)

\begin{abstract}
ABSTRAK
Indonesia menempati urutan ke-3 dengan jumlah perokok terbesar di dunia. Tingginya jumlah perokok didominasi oleh laki-laki. Mirisnya banyak perokok masih berusia remaja. Zat nikotin yang terkandung dalam rokok dapat menyebabkan efek kecanduan dan mengganggu perkembangan otak diusia remaja. Penelitian ini bertujuan untuk menganalisis variabel serta kecenderungannya dalam mempengaruhi intensitas merokok remaja pria di Indonesia tahun 2017. Data yang digunakan merupakan data sekunder yang bersumber dari Survei Demografi dan Kesehatan Indonesia (SDKI) tahun 2017, dengan unit analisis remaja pria merokok usia 15-24 tahun. Adapun metode analisis yang digunakan adalah analisis deskriptif analisis regresi logistik ordinal. Hasil penelitian menunjukkan bahwa variabel status bersekolah, status bekerja, akses radio, status ekonomi rumah tangga, umur, dan keberadaan paparan asap rokok dalam rumah, signifikan mempengaruhi intensitas merokok remaja pria. Dengan adanya penelitian ini, diharapkan edukasi mengenai bahaya rokok terhadap anak dapat dilakukan sejak dini.
\end{abstract}

Kata kunci: intensitas merokok, remaja pria, regresi logistik ordinal

\begin{abstract}
Indonesia is the country with the third largest number of cigarette smokers in the world. Cigarette smokers are dominated by males smokers. However, many smokers are adolescent. The addictive substances contained in cigarettes will cause great addiction and interfere brain development in adolescence. This paper analyzes the cigarette smoking intensity determinants and their tendencies among males adolescents in Indonesia in 2017. The analisys use secondary data from the 2017 Indonesian Demographic and Health Survey (IDHS), with male adolencents smokers aged 15-24 years as the unit of analysis. Data were analyzed using ordinal logistic regression analysis. The results show that school status, work status, radio access, household economic status, age, and the cigarette smoke exposure in the house, were significantly affected the cigarette smoking intensity of males adolescent. These findings suggest that education about danger caused by cigarette smoking for children should be given as early as possible.
\end{abstract}

Keywords: smoke intensity, males adolescent, ordinal logistic regression

\section{PENDAHULUAN}

Rokok merupakan salah satu permasalahan yang masih menjadi perhatian dunia sampai saat ini. Berbagai kebijakan telah diupayakan untuk menekan angka kasus merokok. Namun, meskipun sudah mengetahui bahaya yang diakibatkan, jumlah kasus merokok masih ditemui tinggi di beberapa negara, salah satunya Indonesia. Indonesia merupakan negara urutan ke-3 dengan jumlah perokok terbesar di dunia. Menurut Balitbangkes (2013), rata-rata konsumsi rokok penduduk Indonesia usia 10 tahun ke atas mencapai 12,3 batang rokok per hari. Hasil Survei Sosial Ekonomi Nasional (SUSENAS) Kor tahun 2017 menunjukkan bahwa pengeluaran untuk konsumsi rokok menempati urutan kedua terbesar setelah pengeluaran makanan dan minuman, yaitu sebesar 6,33 persen dari total pengeluaran. Hal ini menunjukkan tingginya tingkat konsumsi rokok di Indonesia.

Di seluruh dunia, diperkirakan bahwa jumlah perokok laki-laki berkali-kali lipat lebih banyak dibanding perokok perempuan terutama di negara berpenghasilan rendah dan menengah (Hitchman, 2011). Prevalensi perokok laki-laki usia $>15$ tahun di Indonesia pada tahun 2011 mencapai angka 67 persen (Global Adult Tobacco Survey (GATS), 2011). Tiga puluh kali lebih tinggi dibanding perokok wanita yang hanya berada pada angka 2,7 persen. Hal ini terjadi karena pandangan masyarakat terhadap perilaku merokok merupakan sesuatu hal yang wajar dilakukan oleh seorang laki-laki dibandingkan perempuan.

Mirisnya, banyak perokok masih berusia remaja. Kementrian Kesehatan (Kemenkes) mengungkapkan bahwa pengguna rokok setiap hari pada remaja dalam rentang usia 15-19 tahun mencapai 11,2 persen dan 
pada rentang usia 20-24 tahun mencapai 27,2 persen. Zat nikotin yang terkandung dalam rokok dapat menyebabkan efek kecanduan dan mengganggu perkembangan otak diusia remaja. Hal ini dapat mengakibatkan kerusakan hampir di seluruh organ misal pernapasan, jantung bahkan menyebabkan stroke dan kanker paru-paru (Kusumawardani, et al., 2018). Selain itu, merokok di usia muda berpotensi meningkatkan risiko untuk menjadi perokok seumur hidupnya. Usia pertama merokok mempengaruhi keberlanjutan seseorang dalam merokok di usia dewasa. Semakin muda usia pertama merokok, maka semakin besar kemungkinan seseorang untuk menjadi perokok berat di masa dewasa (Leventhal et al., dalam Rahmita 2013).

Pengukuran tentang perilaku merokok dapat ditentukan dari jumlah batang rokok yang dihisap. Hal tersebut diduga memiliki korelasi positif dengan dampak negatif yang ditimbulkan dari perilaku merokok. Peningkatan jumlah rokok yang dikonsumsi berdampak terhadap beban penyakit dan kematian. Perokok remaja pria membutuhkan perhatian khusus guna menekan jumlah konsumsi rokok di Indonesia. Hal ini dikarenakan merokok pada usia muda akan meningkatkan risiko ketergantungan yang semakin tinggi terhadap rokok.

Kusumawardhani, et al. (2018) menyebutkan variabel jenis kelamin, umur, pendidikan, status ekonomi, dan provinsi signifikan berhubungan dengan dengan perilaku remaja merokok di Indonesia. Hasilnya, remaja laki-laki memiliki kecenderungen lebih tinggi untuk merokok dibanding dengan perempuan. Variabel umur didapati memiliki hubungan positif dengan perilaku merokok. Sebaliknya, variabel pendidikan dan status ekonomi memiliki hubungan negatif dengan perilaku merokok. Selanjutnya, Amponsah, et al. (2018) menyebutkan bahwa laki-laki dengan status sosial-ekonomi (miskin dan pendidikan rendah) memiliki kecenderungan yang besar untuk merokok. Martini dan Sulistyowati (2005) dalam penelitiannya mendapati bahwa remaja yang tinggal bersama dengan perokok, memiliki kecenderungan untuk juga ikut merokok. Menurut Hardiyanti, dkk (2020), perilaku merokok pada remaja dipengaruhi oleh variabel usia, pendidikan, asuransi kesehatan, pekerjaan, agama, wilayah tempat tinggal, frekuensi penggunaan radio, televisi dan surat kabar.

Berdasarkan pemaparan diatas, peneliti tertarik untuk melakukan penelitian mengenai intensitas merokok remaja pria di Indonesia tahun 2017. Penelitian ini bertujuan untuk mengetahui gambaran umum intensitas merokok remaja pria di Indonesia tahun 2017 dan menganalisis variabel yang mempengaruhi serta kecenderungannya terhadap intensitas merokok remaja pria di Indonesia tahun 2017.

\section{METODE}

\section{Landasan Teori}

\section{Intensitas Merokok}

Menurut Sitopoe (2000), merokok adalah aktivitas membakar tembakau yang kemudian dihisap isinya, baik menggunakan rokok maupun pipa. Seseorang dapat dikatakan perokok jika mereka merokok minimal satu batang sehari dalam kurun waktu sebulan terakhir (Kemenkes, 2013). Asap rokok sangat merugikan terutama dari segi kesehatan. World Health Organization (WHO) menyebutkan beberapa penyakit dapat diakibatkan dari asap rokok. Risiko penyakit ini tak hanya mengancam perokok aktif, namun juga orang yang menghirup asap rokok disekitarnya (perokok pasif).

Pengukuran perilaku merokok seseorang didasarkan atas suatu kriteria. Kriteria tersebut bisa berupa jumlah batang rokok yang dikonsumsi dalam periode waktu tertentu (intensitas merokok). Terdapat tiga kategori perokok berdasarkan jumlah batang rokok yang dikonsumsi, yaitu (Sitopoe, 2000):

a. Perokok ringan yaitu seseorang yang mengonsumsi rokok antara 1-10 batang perhari.

b. Perokok sedang yaitu seseorang yang mengonsumsi rokok antara 11-20 batang perhari

c. Perokok berat yaitu seseorang yang mengonsumsi rokok lebih dari 20 batang perhari.

Perilaku merokok dipengaruhi oleh beberapa faktor. Salah satunya adalah status bersekolah. Secara umum, setiap sekolah memberlakukan aturan yang harus ditaati oleh siswanya. Salah satunya yaitu larangan merokok di lingkungan sekolah. Aturan dirasa penting dalam membentuk lingkungan sosial seseorang. Menurut Green dalam Notoatmodjo (2007), faktor aturan dan lingkungan sangat kuat mempengaruhi perilaku seseorang. Penelitian yang dilakukan oleh Tyas dan Pederson (1998), remaja yang memiliki komitmen terhadap sekolah memiliki kecenderungan yang lebih kecil untuk berperilaku merokok.

Perilaku merokok juga dipengaruhi oleh status bekerja. Menurut Robinson dan Lader (2007), seseorang yang aktif secara ekonomi lebih cenderung untuk merokok dibandingkan seseorang yang tidak aktif secara ekonomi. Menurut Badan Pusat Statistik (BPS), Bekerja adalah kegiatan ekonomi yang dilakukan oleh 
seseorang dengan maksud memperoleh atau membantu memperoleh pendapatan atau keuntungan, paling sedikit 1 jam (tidak terputus) dalam seminggu yang lalu.

Akses informasi merupakan salah satu faktor yang memengaruhi perilaku merokok (Khanal et al., 2013). Akses informasi dapat diperoleh melalui media cetak maupun online. Kemudahan dalam memperoleh informasi dapat mengakibatkan tingginya keinginan seseorang untuk merokok. (Rudi, et al. 2017).

Menurut Sugiarti dalam 'Inayati (2018), semakin tinggi tingkat pendapatan seseorang maka semakin tinggi pula konsumsi rokok pada individu yang berstatus sebagai perokok. Namun, menurut Nugroho dalam 'Inayati (2018), beban ekonomi yang tinggi pada individu kalangan ekonomi bawah juga mendorong tingginya tingkat konsumsi rokok. Dalam penelitian ini Status Ekonomi Rumah Tangga diukur dari indeks kesejahteraan rumah tangga (Wealth Index) yang dibentuk dengan pendekatan multivariat analisis Principal Component Polychoric. Penghitungan Wealth Index dijelaskan lebih lanjut dalam Laporan Survei Demografi dan Kesehatan Indonesia Tahun 2017 Buku Remaja.

Penelitian oleh Reda, et al. (2012) menemukan bahwa variabel umur memiliki hubungan positif yang signifikan dengan perilaku merokok pada remaja. Menurut BPS, umur merupakan banyaknya tahun yang telah dijalani seseorang dari lahir hingga ulang tahun terakhir saat pencacahan. Pengkategorian umur pada penelitian ini mengacu pada ketentuan Departemen Kesehatan (Depkes) RI (2009).

Paparan asap rokok di dalam rumah mempengaruhi perilaku merokok remaja. Paparan asap rokok di dalam rumah merupakan keberadaan paparan asap rokok dari seseorang yang merokok di dalam rumah, tidak hanya anggota rumah tangga. Rudatsikira, et al. (2007) mengungkapkan dalam hasil penelitiannya, bahwa remaja dengan orang tua perokok (terdapat paparan asap rokok dalam rumah) memiliki kecenderungan lebih besar untuk merokok dibanding remaja dengan orang tua non perokok.

\section{Metode Analisis}

Metode analisis yang digunakan dalam penelitian ini adalah analisis deskriptif dan analisis inferensia. Analisis deskriptif digunakan untuk mengetahui gambaran umum intensitas merokok remaja pria di Indonesia tahun 2017. Sedangkan analisis inferensia digunakan untuk menganalisis variabel serta kecenderungannya dalam mempengaruhi intensitas merokok remaja pria di Indonesia tahun 2017 menggunakan regresi logistik ordinal.

Regresi logistik ordinal merupakan salah satu metode analisis yang dapat digunakan untuk menganalisis variabel tak bebas yang berupa data diskrit berskala ordinal. (Hosmer dan Lemeshow, 2000). Misalkan variabel tak bebas $\mathrm{Y}$ berskala ordinal memiliki $\mathbf{J}$ kategori dan $\mathbf{x}=\left(\mathrm{x}_{1}, \mathrm{x}_{2}, \ldots, \mathrm{X}_{\mathrm{p}}\right)^{\prime}$ merupakan vektor variabel bebas, maka peluang variabel tak bebas $\mathrm{Y}$ kategori ke-j pada variabel bebas $\mathrm{X}$ tertentu dapat dinyatakan sebagai berikut (Agresti, 2002) :

$$
\mathrm{P}(\mathrm{Y}=\mathrm{j} \mid \mathbf{x})=\pi_{\mathrm{j}}(\mathbf{x})
$$

Model respon kategorik berskala ordinal didapatkan dengan membentuk fungsi logit peluang kumulatif untuk tiap kategori ke-j. Cumulative logit models merupakan model yang didapatkan dengan membandingkan peluang kumulatif. Model logit kumulatif didefinisikan dengan (Agresti, 2002):

$$
\begin{aligned}
& \operatorname{logit}[P(Y \leq j \mid x)]=\log \left[\frac{P(Y \leq j \mid x)}{1-P(Y \leq j \mid x)}\right] \\
& =\log \left[\frac{\pi_{1}(\mathrm{x})+\pi_{2}(\mathrm{x})+\cdots \cdot+\pi_{j}(\mathrm{x})}{1-\left\{\pi_{1}(\mathrm{x})+\pi_{2}(\mathrm{x})+\cdots \cdot+\pi_{j}(\mathrm{x})\right\}}\right] \\
& =\alpha_{j}+\boldsymbol{x}^{\prime} \boldsymbol{\beta}
\end{aligned}
$$
2002).

dimana, $\mathrm{j}=1,2, \ldots, \mathrm{J}-1$ dengan $\alpha$ adalah threshold serta $\boldsymbol{\beta}$ merupakan vektor koefisien regresi (Agresti,

Model yang terbentuk dari variabel tak bebas dengan $\mathbf{J}$ kategori adalah sebanyak J-1. Terdapat satu koefisien regresi $(\beta)$ untuk setiap variabel bebas dalam suatu model, namun nilai intercept $(\alpha)$ akan berbeda untuk setiap J-1 model yang dihasilkan. (Kleinbaum dan Klein, 2010).

Adapun langkah-langkah regresi logistik ordinal dalam peneltian ini adalah sebagai berikut:

1. Estimasi Parameter

Metode maximum likelihood menaksir parameter-parameter model dalam regresi logistik dengan memberikan nilai estimasi $\beta$ yang dapat memaksimumkan fungsi likelihood. Fungsi yang mendasari metode maximum likelihood untuk n sampel independen, adalah (Hosmer dan Lemeshow, 2000):

$$
\begin{aligned}
l(\boldsymbol{\beta}) & =\prod_{i=1}^{n} \prod_{j=1}^{J} \pi_{i}\left(\boldsymbol{x}_{\boldsymbol{i}}\right)^{y_{j i}} \\
& =\prod_{i=1}^{n}\left[\pi_{1}\left(\boldsymbol{x}_{\boldsymbol{i}}\right)^{y_{1 i}} \pi_{2}\left(\boldsymbol{x}_{\boldsymbol{i}}\right)^{y_{2 i}} \ldots \pi_{J}\left(\boldsymbol{x}_{\boldsymbol{i}}\right)^{y_{j i}}\right]
\end{aligned}
$$


dimana, $\mathrm{i}=1,2, \ldots, \mathrm{n}$ adalah jumlah observasi dan $\mathbf{y}=\left(y_{1 i}, y_{2 i}, \ldots, y_{J i}\right)^{\prime}$ adalah kejadian sampel acak ke-i yang masuk ke dalam kategori $\mathrm{j}$ pada variabel tak bebas dimana $\mathrm{j}=1,2, \ldots, \mathrm{J}$

Langkah selanjutnya untuk memperoleh estimasi $\beta$ adalah dengan melakukan diferensiasi atau penurunan pada fungsi ln-likelihood terhadap parameter yang akan diestimasi dengan syarat persamaannya disamadengankan nol. (Agresti 2002).

2. Uji Asumsi Parallel Lines

Uji asumsi parallel lines berguna untuk memastikan bahwa pengaruh setiap variabel bebas adalah sama pada setiap kategori variabel tak bebas. Hipotesis yang digunakan adalah sebagai berikut (Azen dan Walker, 2011) :

$\mathrm{H}_{0}$ : Model menghasilkan koefisien regresi (slope) yang sama

$\mathrm{H}_{1}$ : Model tidak menghasilkan koefisien regresi (slope) yang sama

Statistik Uji :

$$
P L=-2 \ln \left[\frac{l_{0}}{l_{1}}\right] \sim \chi_{p(j-2)}^{2}
$$

dimana :

$l_{0}$ : fungsi likelihood dengan variabel bebas yang mengasumsikan parallel lines

$l_{1}$ : fungsi likelihood dengan variabel bebas yang tidak mengasumsikan parallel lines

$\mathrm{H}_{0}$ akan ditolak ketika $P L>\chi_{\alpha, p(j-2)}^{2}$ atau ketika $p$-value $<\alpha$. p adalah jumlah parameter dan $\mathrm{j}$ adalah jumlah kategori variabel tak bebas.

3. Uji Kesesuaian Model

Uji kesesuaian model digunakan untuk menguji apakah suatu model yang terbentuk fit/layak untuk menganalisis suatu data. Hipotesis yang digunakan adalah sebagai berikut (Azen dan Walker, 2011) :

$\mathrm{H}_{0}$ : distribusi frekuensi data observasi sama dengan data ekspektasi (model cocok)

$\mathrm{H}_{1}$ : distribusi frekuensi data observasi berbeda dengan data ekspektasi (model tidak cocok)

Statistik Uji :

$$
\chi^{2}=\sum_{i=1}^{I} \sum_{j=1}^{J} \frac{\left(o_{i j}-e_{i j}\right)^{2}}{e_{i j}} \sim \chi_{I(J-1)-r}^{2}
$$

dimana :

$\mathrm{I}=$ jumlah semua kemungkinan kombinasi variabel bebas

$\mathrm{J}=$ jumlah kategori pada variabel tak bebas

$\mathrm{r} \quad=$ jumlah parameter yang diestimasi

$\mathrm{o}_{\mathrm{ij}}=$ nilai observasi baris ke-i kategori ke- $\mathrm{j}$

$\mathrm{e}_{\mathrm{ij}}=$ nilai harapan baris ke-i kategori ke-j

$\mathrm{H}_{0}$ akan ditolak ketika $\chi^{2}>\chi_{\alpha ; I(J-1)-r}^{2}$ atau ketika $p$-value $<\alpha$.

4. Uji signifikansi penduga parameter secara simultan

Uji simultan digunakan untuk mengetahui pengaruh nyata seluruh variabel bebas terhadap variabel tak bebas dalam model secara bersama-sama (simultan). Hipotesis yang digunakan adalah sebagai berikut (Hosmer dan Lemeshow, 2000):

$\mathrm{H}_{0}: \beta_{1}=\beta_{2}=\cdots=\beta_{\mathrm{p}}=0$ (Tidak ada pengaruh seluruh variabel bebas terhadap variabel tak bebas) $\mathrm{H}_{1}$ : Minimal terdapat satu $\beta_{\mathrm{k}} \neq 0$ (Minimal terdapat satu variabel bebas yang berpengaruh terhadap variabel tak bebas)

Statistik uji :

$$
G=-2 \ln \left[\frac{l_{0}}{l_{1}}\right] \sim \chi_{p}^{2}
$$

dimana :

$l_{0}=$ fungsi maximum likelihood tanpa variabel bebas

$l_{1}=$ fungsi maximum likelihood dengan variabel bebas

$\mathrm{H}_{0}$ akan ditolak ketika $\mathrm{G}>\chi_{\alpha, p}^{2}$ atau ketika $p$-value $<\alpha$.

5. Uji signifikansi penduga parameter secara parsial 
Uji parsial merupakan uji lanjutan dari uji simultan. Jika uji simultan menghasilkan keputusan tolak $\mathrm{H}_{0}$, maka perlu dilakukan uji parsial. Uji Parsial berguna untuk menguji signifikansi masingmasing variabel. Hipotesis yang digunakan adalah sebagai berikut (Hosmer dan Lemeshow, 2000):

$\mathrm{H}_{0}: \beta_{\mathrm{k}}=0, \mathrm{k}=1,2, \ldots, \mathrm{p}$. (variabel bebas ke-k tidak berpengaruh signifikan terhadap variabel tak bebas)

$\mathrm{H}_{1}: \beta_{\mathrm{k}} \neq 0, \mathrm{k}=1,2, \ldots, \mathrm{p}$. (variabel bebas ke-k berpengaruh signifikan terhadap variabel tak bebas)

Statistik Uji :

$$
W_{k}=\left(\frac{\widehat{\beta}_{k}}{\operatorname{Se}\left(\widehat{\beta}_{k}\right)}\right)^{2} \sim \chi_{1}^{2}
$$

dimana:

$\hat{\beta}_{\mathrm{k}} \quad=$ nilai penduga $\beta_{k}$

$\operatorname{Se}\left(\widehat{\beta}_{\mathrm{k}}\right)=$ standar eror dari $\hat{\beta}_{\mathrm{k}}$

6. Penghitungan rasio kecenderungan (odds ratio)

Interpretasi dalam regresi logitik menggunakan odds ratio. Odds ratio menunjukkan tingkat kecenderungan suatu bagian populasi pada kategori tertentu terhadap bagian populasi pada kategori lainnya dalam variabel bebas yang berpengaruh signifikan terhadap variabel tak bebas.

\section{Data dan Sumber Data}

Data yang digunakan dalam penelitian ini merupakan data sekunder cross-sectional yaitu Survei Demografi dan Kesehatan Indonesia (SDKI) Tahun 2017. SDKI merupakan bagian dari program internasional Demographic and Health Survey (DHS) yang dirancang untuk mengumpulkan data fertilitas, keluarga berencana, kesehatan ibu dan anak, dan juga informasi remaja. Pengumpulan data berlangsung dari tanggal 24 Juli hingga 30 September 2017.

Pada penelitian ini hanya menggunakan data dari penduduk remaja pria berusia 15-24 tahun yang merokok. Pengumpulan data dilakukan dengan cara wawancara yang diperoleh dari dua kuesioner yaitu kuesioner rumah tangga (RT) dan kuesioner remaja pria (RP). Dibandingkan dengan data dari survei lain, kuesioner pada remaja pria mencakup informasi yang lebih luas mengenai kesehatan reproduksi remaja guna mencegah pernikahan dini, kehamilan yang tidak diinginkan, penggunaan merokok, penggunaan alkohol, dan HIV/AIDS. Adapun variabel-variabel yang digunakan dalam penelitian ini adalah sebagai berikut.

Tabel 1. Variabel penelitian.

\begin{tabular}{|c|c|c|c|c|}
\hline Nama Variabel & Kategori & Cut-off & Dummy & Kode \\
\hline (1) & (2) & (3) & (3) & (4) \\
\hline \multirow{3}{*}{ Intensitas merokok } & Perokok ringan* & 1-10 rokok per-hari & 0 & $\mathrm{Y}$ \\
\hline & Perokok sedang & 11-20 rokok per-hari & 1 & \\
\hline & Perokok berat & $\geq 20$ rokok per-hari & 2 & \\
\hline \multirow[t]{2}{*}{ Status bersekolah } & Bersekolah * & & 0 & D1 \\
\hline & Tidak bersekolah & - & 1 & \\
\hline \multirow[t]{2}{*}{ Status bekerja } & Tidak bekerja* & & 0 & D2 \\
\hline & Bekerja & - & 1 & \\
\hline \multirow[t]{2}{*}{ Akses radio } & Tidak pernah $*$ & & 0 & D3 \\
\hline & Pernah & - & 1 & \\
\hline \multirow[t]{2}{*}{ Akses internet } & Tidak pernah $*$ & & 0 & D4 \\
\hline & Pernah & - & 1 & \\
\hline Status ekonomi & Tinggi $*$ & & 0 & D51 \\
\hline \multirow[t]{2}{*}{ rumah tangga } & Sedang & - & 1 & D52 \\
\hline & Rendah & & 2 & \\
\hline \multirow[t]{2}{*}{ Umur } & Remaja awal * & $15-16$ tahun & 0 & D6 \\
\hline & Remaja akhir & $17-24$ tahun & 1 & \\
\hline Paparan asap rokok & Tidak Terpapar asap rokok * & & 0 & D7 \\
\hline dalam rumah & Terpapar asap rokok & & 1 & \\
\hline
\end{tabular}

Sumber: Survei Demografi Kesehatan Indonesia 2017 (diolah)

*kategori referensi 


\section{HASIL DAN PEMBAHASAN}

Persentase perilaku intensitas merokok remaja pria tiap kategori dihitung dengan cara membagi jumlah remaja pria yang merokok pada kategori tersebut dengan jumlah total remaja pria yang merokok setiap hari. Gambar 1 menunjukkan persentase perilaku remaja pria merokok setiap hari menurut intensitasnya. Dari 4603 remaja pria merokok setiap hari di Indonesia, didapati bahwa $57 \%$ remaja pria merokok merupakan perokok ringan, $39 \%$ perokok sedang, dan sisanya merupakan perokok berat yaitu $4 \%$.

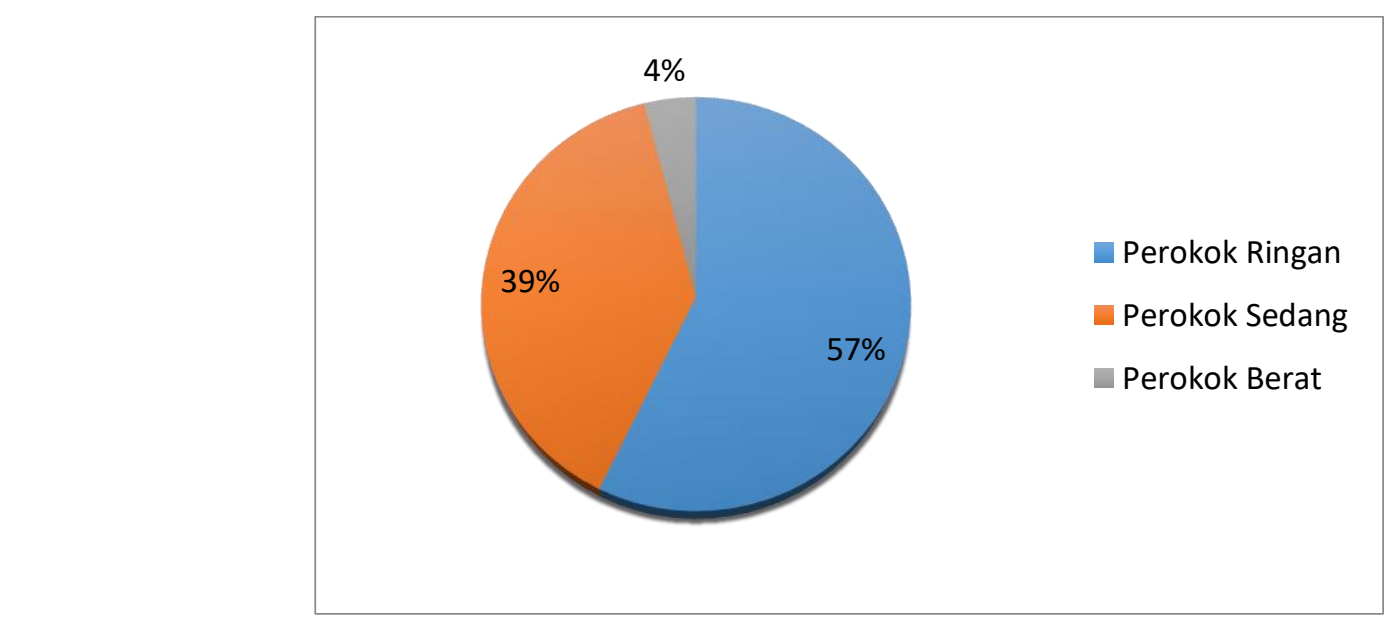

Sumber: Survei Demografi Kesehatan Indonesia 2017 (diolah)

Gambar 1. Persentase remaja pria merokok menurut intensitasnya dalam sehari di Indonesia Tahun 2017

Tabel 2 menunjukkan gambaran umum karakteristik intensitas merokok remaja pria di Indonesia tahun 2017. Pada remaja pria merokok yang tidak bersekolah, sebanyak 51,8 persen merupakan perokok ringan, 43,7 persen merupakan perokok sedang, dan 4,5 persen merupakan perokok berat. Sedangkan pada remaja pria merokok yang masih bersekolah, 74,4 persen merupakan perokok ringan, 23,4 persen merupakan perokok sedang dan 2,3 persen merupakan perokok berat.

Persentase remaja pria perokok ringan lebih banyak berstatus sebagai remaja yang tidak bekerja dibanding dengan yang bekerja. Sebaliknya, persentase remaja pria perokok sedang dan berat lebih banyak terdapat pada remaja yang bekerja dibanding dengan yang tidak bekerja. Tercatat 69,9 persen remaja yang tidak bekerja berstatus sebagai perokok ringan, 27,8 persen perokok sedang, dan 2,3 persen merupakan perokok berat. Sedangkan pada remaja pria yang bekerja, terdapat 51,1 persen merupakan perokok ringan, 44,2 persen merupakan perokok sedang, dan 4,7 persen sisanya merupakan perokok berat.

Akses informasi dapat diperoleh melalui internet dan radio. Pada remaja pria yang tidak pernah mengakses/mendengarkan radio, sebanyak 58,7 persen berstatus sebagai perokok ringan, 37,9 persen merupakan perokok sedang, dan 3,3 persen sisanya merupakan perokok berat. Sedangkan pada remaja pria yang pernah mengakses/mendengarkan radio, sebanyak 55,5 persen merupakan perokok ringan, 39,9 persen merupakan perokok sedang, dan 4,7 persen sisanya merupakan perokok berat. Pada remaja pria merokok yang tidak pernah mengakses internet selama 12 bulan terakhir,sebanyak 55,5 persen remaja pria merokok berstatus sebagai perokok ringan, 41,2 persen berstatus sebagai perokok sedang, dan 3,3 persen sisanya adalah perokok berat. Sedangkan pada remaja pria yang pernah mengakses internet, 57,5 persen diantaranya merupakan perokok ringan, 38,4 persen perokok sedang, dan4,1 persen merupakan perokok berat. Persentase perokok ringan dan berat ditemukan lebih banyak pada remaja yang pernah mengakses internet. Sedangkan persentase perokok sedang ditemukan lebih banyak pada remaja yang tidak pernah mengakses internet.

Pada tingkatan ekonomi rumah tangga rendah, sebanyak 56,7 persen remaja pria merokok berstatus sebagai perokok ringan, 39,6 persen merupakan perokok sedang, dan 3,6 persen merupakan perokok berat. Pada tingkatan ekonomi rumah tangga sedang, sebanyak 59,1 persen merupakan perokok ringan, 36,9 persen merupakan perokok sedang, dan 4,1 persen merupakan perokok berat. Terakhir, pada tingkatan ekonomi tinggi, sebanyak 56,7 persen merupakan perokok ringan, 39 persen merupakan perokok sedang, dan 4,4 persen merupakan perokok berat.

Variabel umur dikategorikan ke dalam dua kelompok yaitu remaja awal dan remaja akhir. Menurut kategori umur remaja awal, sebanyak 77,2 persen berstatus sebagai perokok ringan, 21,6 merupakan perokok sedang, dan 1,2 merupakan perokok berat. Sedangkan pada remaja akhir, 54,8 persen merupakan perokok ringan, 40,9 persen merupakan perokok sedang, dan 4,3 persen sisanya merupakan perokok berat. 
Sebanyak 68,6 persen remaja pria perokok ringan, 28 persen perokok sedang, dan 3,4 persen perokok berat, ditemukan pada rumah yang tidak ada paparan asap rokok. Sedangkan pada rumah yang terdapat paparan asap rokok, terdapat 56,2 persen perokok ringan, 39,8 persen perokok sedang, dan 4 persen sisanya merupakan perokok berat. Persentase remaja pria perokok ringan lebih banyak ditemukan pada remaja yang tinggal pada rumah yang tidak terdapat paparan asap rokok. Sebaliknya, persentase remaja pria perokok sedang dan berat lebih banyak ditemukan pada remaja yang tinggal pada rumah yang terdapat paparan asap rokok.

Tabel 2. Karakteristik intensitas merokok remaja pria di Indonesia tahun 2017.

\begin{tabular}{|c|c|c|c|c|}
\hline \multirow[t]{3}{*}{ Variabel } & \multicolumn{4}{|c|}{ Intensitas Merokok (\%) } \\
\hline & (2) & (3) & (4) & (5) \\
\hline & & Perokok ringan & Perokok sedang & Perokok berat \\
\hline \multirow[t]{2}{*}{ Status Bersekolah } & Bersekolah & 74,4 & 23,4 & 2,3 \\
\hline & Tidak Bersekolah & 51,8 & 43,7 & 4,5 \\
\hline \multirow[t]{2}{*}{ Status Bekerja } & Tidak Bekerja & 69,9 & 27,8 & 2,3 \\
\hline & Bekerja & 51,1 & 44,2 & 4,7 \\
\hline \multirow[t]{2}{*}{ Akses Radio } & Tidak Pernah & 58,7 & 37,9 & 3,3 \\
\hline & Pernah & 55,5 & 39,9 & 4,7 \\
\hline \multirow[t]{2}{*}{ Akses Internet } & Tidak Pernah & 55,5 & 41,2 & 3,3 \\
\hline & Pernah & 57,5 & 38,4 & 4,1 \\
\hline \multirow{3}{*}{$\begin{array}{l}\text { Status Ekonomi } \\
\text { Rumah Tangga }\end{array}$} & Tinggi & 56,7 & 39,0 & 4,4 \\
\hline & Sedang & 59,1 & 36,9 & 4,1 \\
\hline & Rendah & 56,7 & 39,6 & 3,6 \\
\hline \multirow[t]{2}{*}{ Umur } & Remaja awal & 77,2 & 21,6 & 1,2 \\
\hline & Remaja akhir & 54,8 & 40,9 & 4,3 \\
\hline \multirow{2}{*}{$\begin{array}{l}\text { Paparan Asap } \\
\text { dalam Rumah }\end{array}$} & Tidak ada & 68,6 & 28,0 & 3,4 \\
\hline & Ada & 56,2 & 39,8 & 4,0 \\
\hline
\end{tabular}

Sumber: Survei Demografi Kesehatan Indonesia 2017 (diolah)

Asumsi yang harus dipenuhi untuk analisis regresi logistik ordinal model cumulative logit adalah asumsi parallel lines. Berdasarkan hasil uji parallel lines, didapatkan nilai nilai $\chi_{\text {hitung }}^{2}$ sebesar 7,205 (lebih kecil dari nilai $\chi_{0,05 ; 8}^{2}=15,51$ ) dan $\mathrm{p}$-value 0,515 (lebih besar dari $\mathrm{p}$-value $=5 \%$ ). Dengan demikian keputusan yang diperoleh adalah gagal tolak hipotesis nol. Hal ini berati, dengan tingkat signifikansi 5 persen, dapat disimpulkan bahwa model menghasilkan koefisien regresi (slope) yang sama untuk setiap tingkatan perilaku intensitas merokok remaja pria di Indonesia.

Pada hasil uji kesesuaian model, diperoleh nilai $\chi_{\text {hitung }}^{2}$ sebesar 281,576 (lebih kecil dari $\chi_{0,05 ; 262}^{2}=$ 300,755) dan p-value sebesar 0,194 lebih besar dari 5\%. Keputusan yang diambil dari hasil yang diperoleh adalah gagal tolak hipotesis nol. Kesimpulannya, dengan tingkat kepercayaan 95 persen, model yang digunakan telah sesuai atau layak untuk menjelaskan data yang ada.

Setelah model memenuhi asumsi parallel lines dan model dinyatakan cocok untuk menjelaskan data yang ada, selanjutnya dilakukan pengujian parameter secara simultan. Berdasarkan hasil yang ada, diperoleh nilai $\mathrm{G}$ sebesar 304,650 (lebih besar dari nilai $\chi_{0,05 ; 8}^{2}=15,51$ ) dan p-value 0,000 (lebih kecil dari p-value $=$ $5 \%$ ). Dengan demikian keputusan yang diperoleh adalah tolak hipotesis nol. Hal ini berati, dengan tingkat signifikansi 5 persen, dapat disimpulkan bahwa, terdapat minimal satu variabel bebas yang memiliki pengaruh signifikan terhadap tingkatan intensitas merokok remaja pria di Indonesia.

Setelah memperoleh hasil tolak hipotesis nol dari uji simultan, maka tahapan selanjutnya adalah melakukan pengujian parameter secara parsial. Tabel 2 memperlihatkan hasil uji parsial masing-masing variabel menggunakan statistik Wald. Nilai statistik Wald dari masing-masing variabel dibandingkan dengan $\chi_{0,05 ; 1}^{2}=3,841$ atau p-value dibandingkan dengan $\alpha=5 \%$. Hipotesis nol ditolak apabila nilai statistik wald masing-masing variabel lebih besar dari 3,841 atau p-value kurang dari 0,05. 
Tabel 3. Hasil pengujian parameter secara parsial antara variabel bebas dengan intensitas merokok

\begin{tabular}{lccc}
\hline \multicolumn{1}{c}{ Variabel } & \multicolumn{1}{c}{$\hat{\beta}$} & p-value & OR \\
\hline \multicolumn{1}{c}{$(1)$} & $(2)$ & $(3)$ & $(4)$ \\
\hline Variabel Tak Bebas & & & \\
Intensitas merokok remaja pria & & & \\
Perokok Berat & $-5,055$ & 0,000 & \\
Perokok Sedang & $-2,069$ & 0,000 & \\
Variabel Bebas & & & \\
Status Bersekolah* & 0,661 & 0,000 & 1,936 \\
Status Bekerja* & 0,529 & 0,000 & 1,697 \\
Akses Radio* & 0,152 & 0,012 & 1,164 \\
Akses Internet & $-0,048$ & 0,584 & 0,953 \\
Status Ekonomi Rumah Tangga Rendah* & $-0,187$ & 0,011 & 0,829 \\
Status Ekonomi Rumah Tangga Sedang* & $-0,200$ & 0,022 & 0,818 \\
Umur* & 0,690 & 0,000 & 1,993 \\
Paparan asap rokok dalam rumah* & 0,400 & 0,001 & 1,491 \\
\hline
\end{tabular}

Sumber: Survei Demografi dan Kesehatan Indonesia Tahun 2017 (diolah)

*) Signifikan pada $5 \%$

Hasilnya, variabel status bersekolah, status bekerja, akses radio, status ekonomi rumah tangga, umur, dan paparan asap rokok dalam rumah memiliki nilai statistik Wald yang lebih besar dari 3,481 atau p-value lebih kecil dari 0,05. Dengan hasil ini, keputusan yang diambil adalah tolak hipotesis nol. Artinya, dengan tingkat signifikansi $5 \%$, dapat disimpulkan bahwa terdapat pengaruh varibabel-variabel tersebut secara parsial terhadap tingkatan perilaku intensitas merokok remaja pria di Indonesia.Sedangkan variabel akses internet tidak signifikan mempengaruhi tingkatan perilaku intensitas merokok remaja pria di Indonesia.

Berdasarkan tabel 3, dapat dibentuk model persamaan regresi logistik ordinal yang menjelaskan variabel-variabel yang mempengaruhi tingkatan perilaku merokok remaja pria di Indonesia. Persamaannya adalah sebagai berikut:

a. Persamaan regresi logistik ordinal untuk remaja pria perokok berat dan sedang dibandingkan dengan remaja pria perokok ringan

$$
\begin{aligned}
\operatorname{logit}[P(Y \geq 1)= & -2,069+0,661 D_{1}{ }^{*}+0,529 D_{2}{ }^{*}+0,152 D_{3}{ }^{*}-0,048 D_{4}- \\
& 0,187 D_{51}{ }^{*}-0,200 D_{52}{ }^{*}+0,690 D_{6}{ }^{*}+0,400 D_{7}{ }^{*}
\end{aligned}
$$

b. Persamaan regresi logistik ordinal untuk remaja pria perokok berat dibandingkan dengan remaja pria perokok ringan dan sedang

$$
\begin{aligned}
\operatorname{logit}[P(Y \geq 2)= & -5,055+0,661 D_{1}{ }^{*}+0,529 D_{2}{ }^{*}+0,152 D_{3}{ }^{*}-0,048 D_{4}- \\
& 0,187 D_{51}{ }^{*}-0,200 D_{52}{ }^{*}+0,690 D_{6}{ }^{*}+0,400 D_{7}{ }^{*}
\end{aligned}
$$

dimana :

*) Signifikan pada $5 \%$

$\mathrm{D}_{1}=$ Status bersekolah

$\mathrm{D}_{2}=$ Status bekerja

$\mathrm{D}_{3}=$ Akses radio

$\mathrm{D}_{4}=$ Akses internet

$\mathrm{D}_{51}=$ Status ekonomi tinggi

$\mathrm{D}_{52}=$ Status ekonomi sedang

$\mathrm{D}_{6}=$ Umur

$\mathrm{D}_{7}=$ Paparan asap rokok dalam rumah

Kecenderungan masing-masing variabel dalam regresi logistik dinyatakan dalam bentuk odds ratio yang diperoleh dari eksponensial beta. Tabel 3 kolom 4 menampilkan odds ratio dari masing-masing variabel yang signifikan mempengaruhi intensitas perilaku merokok remaja pria di Indonesia. Masingmasing nilai odds ratio akan dijelaskan sebagai berikut: 
Remaja pria yang sudah tidak bersekolah memiliki kecenderungan 1,936 kali lebih besar untuk berperilaku menjadi minimal perokok sedang daripada remaja pria yang masih bersekolah. Hal ini diduga dipengaruhi oleh perbedaan lingkungan serta aturan antara remaja yang masih bersekolah dan tidak bersekolah. Remaja yang masih bersekolah terikat dengan aturan sekolah untuk tidak merokok. Secara tidak langsung, aturan yang ada membentuk kebiasaan dan perilaku seseorang.

Nilai odds ratio untuk variabel status bekerja adalah sebesar 1,697. Hal ini berarti bahwa remaja pria yang bekerja/memiliki pekerjaan paling sedikit 1 jam dalam semingu terakhir memiliki kecenderungan 1,697 kali lebih besar untuk berperilaku menjadi minimal perokok sedang daripada remaja pria yang tidak bekerja/memiliki pekerjaan dengan asumsi variabel-variabel lain konstan. Hal ini senada dengan penelitian yang dilakukan oleh Robinson dan Lader (2007). Dalam penelitiannya, Robinson dan dan Lader mengemukakan bahwa seseorang yang aktif secara ekonomi lebih cenderung untuk merokok dibandingkan seseorang yang tidak aktif secara ekonomi. Dalam dunia kerja, konflik dan stress kerja merupakan hal yang tidak bisa dihindari. Notoatmojo (2007) menyatakan bahwa semakin berat tingkat stress seseorang, maka semakin banyak jumlah batang rokok yang dihisap.

Kecenderungan remaja pria yang mengakses radio selama 12 bulan terakhir pada saat periode pencacahan adalah 1,164 lebih besar untuk berperilaku menjadi minimal perokok sedang dibandingkan dengan remaja pria yang tidak mengakses radio dengan asumsi variabel-variabel lain konstan. Hasil penelitian ini sejalan dengan Rudi et al. (2017) yang menyatakan bahwa akses informasi yang baik membuat keinginan merokok tinggi karena remaja dapat dengan mudah memperoleh informasi. Hal ini diduga berkaitan dengan adanya paparan iklan rokok di media massa maupun elektronik.

Remaja pria yang berada pada rumah tangga dengan keadaan ekonomi rendah memiliki kecenderungan 0,829 kali lebih kecil untuk berperilaku menjadi minimal perokok sedang dibanding dengan remaja pria yang berada pada rumah tangga dengan keadaan ekonomi tinggi dengan asumsi variabel-variabel lain konstan. Sedangkan remaja pria yang berada pada rumah tangga dengan keadaan ekonomi sedang memiliki kecenderungan 0,818 kali lebih kecil untuk berperilaku menjadi minimal perokok sedang dibanding dengan remaja pria yang berada pada rumah tangga dengan keadaan ekonomi tinggi dengan asumsi variabel-variabel lain konstan. Dengan kata lain, remaja dengan keadaan ekonomi rumah tangga rendah dan sedang lebih cenderung untuk menjadi perokok ringan. Remaja dengan keadaan rumah tangga miskin memiliki kecenderungan yang lebih kecil untuk berlanjut menjadi perokok sedang dan berat karena keterbatasan ekonomi. Semakin besar jumlah batang rokok yang dikonsumsi, maka semakin tinggi pula pengeluaran untuk merokok.

Remaja pria yang berada pada masa remaja akhir memiliki kecenderungan 1,993 kali lebih besar untuk berperilaku menjadi minimal perokok sedang dibanding dengan remaja pria yang berada pada masa remaja awal dengan asumsi variabel-variabel lain konstan. Peningkatan umur seringkali sejalan dengan peningkatan stress. Dalam mengekspresikan stress, tiap-tiap remaja memiliki cara yang berbeda. Beberapa diantaranya yaitu melakukan uji coba praktik berisiko dan eksperimen dengan zat seperti tembakau (Reda et al., 2012).

Remaja pria yang tinggal pada rumah yang terdapat paparan asap rokok memiliki kecenderungan 1,491 lebih besar untuk berperilaku menjadi minimal perokok sedang dibanding dengan remaja pria yang tinggal pada rumah yang tidak terdapat paparan asap rokok. Paparan asap rokok dikaitkan dengan keberadaan perokok lain dalam rumah. Hasil penelitian ini sejalan dengan Rudatsikira et al. (2007) yang mengungkapkan bahwa remaja yang terpapar asap rokok (dari orang tua) memiliki kecenderungan lebih tinggi untuk menjadi perokok dibanding dengan remaja yang tidak terpapar asap rokok. Selain itu, Green dalam Notoatmodjo (2007) mengungkapkan bahwa faktor lingkungan sangat kuat mempengaruhi perilaku merokok.

\section{KESIMPULAN}

Berdasarkan hasil analisis deskriptif, sekitar 57 persen remaja pria merokok di Indonesia merupakan perokok ringan, 39 persen perokok sedang, dan 4 persen sisanya merupakan perokok berat. Selanjutnya, analisis regresi logistik ordinal digunakan untuk menganalisis variabel-variabel yang mempengaruhi perilaku intensitas merokok remaja pria di Indonesia tahun 2017. Menggunakan model proportional odds model, dapat diketahui bahwa terdapat enam variabel yang signifikan mempengaruhi perilaku intensitas merokok remaja pria di Indonesia tahun 2017. Enam variabel tersebut yaitu status bersekolah, status bekerja, akses radio, status ekonomi rumah tangga, umur, dan keberadaan paparan asap rokok dalam rumah.

Dari keenam variabel signifikan, variabel umur memiliki kecenderungan terbesar dalam mempengaruhi intensitas merokok. Remaja pria dengan karakteristik tidak bersekolah, bekerja, status ekonomi rumah 
tangga tinggi, berumur remaja akhir, dan terpapar asap rokok di rumah memiliki kecenderungan yang lebih tinggi untuk berperilaku sebagai perokok berat.

\section{DAFTAR PUSTAKA}

Agresti, Alan. (2002). Categorical Data Analysis (2nd ed). New Jersey: John Wiley \& Sons, Inc.

Azen, R \& Walker, C.M. (2011) . Categorical data analysis for the behavioral and social sciences.

New York: Taylor \& Francis Group.

Badan Pusat Statistik. (2017). Pengeluaran Untuk Konsumsi Penduduk Indonesia Per Provinsi. Jakarta: BPS.

Barman, S.K. Pukkinen, L., Kaprio, J. and Rose, R.J. (2004) Inattentiveness, Parental Smoking and Adolescent Smoking Initiation. Addiction, 99(8), 1049-1061

Hardiyanti, V., Efendi, F., \& Kusumaningrum, T. (2020). Determinan Perilaku Merokok pada Remaja Pria : Literatur Review. Indonesian J. of Community Health Nurs. J., 5(1), 21-25.

Hitchman, S. C., \& Fong G. T. (2011). Gender empowerment and female-to-male smoking prevalence ratios. Bulletin of the World Health Organization, 89(3), 195-202

Hosmer \& Lemeshow. (2000). Applied Logistic Regression (2nd ed). Canada: John Wiley \& Sons, Inc.

Inayati, Likha (2018). Faktor-Faktor yang Mempengaruhi Konsumsi Rokok Tenaga Kerja di Indonesia [Skripsi]. Yogyakarta:Universitas Negeri Yogyakarta

Kementrian Kesehatan. (2013). Riset Kesehatan Dasar 2013. Jakarta: Balitbangkes.

Khanal, V., Adhikari, M. and Karki, S. (2013). Social Determinants of Tobacco Consumption among Nepalese Men: Findings from Nepal Demographic and Health Survey 2011. Harm Education Journal, 10,10 .

Kleinbaum, D.G., \& Klein, M. (2010). Logistic Regression: A Self-Learning Text. 3rd edition. New York: Springer Science

Kusumawardhani, N., Tarigan, I., Suparmi, \& Schlotheuber, A. (2018). Socio-Economic, demographic and geographic coreelates of cigarette smoking among Indonesian adolescent: result from the 2013 Indonesian Basic Health Research (RISKESDAS) survey. Global Health Action, 11(sup1), 1467605

Martini, S., Sulistyowati, M. (2005). The Determinants of Smoking Behavior among Teenagers in East Java Province, Indonesia. HNP discussion paper; economics of tobacco control paper, 32.

Nketiah-Amponsal, E., Afful-Mensah, G., \& Ampaw, S. (2018). Determinants of cigarette smoking and smoking intensity among adulth males in Ghana. BMC Public Health, 18(1),941.

Notoatmojo S. (2007). Promosi Kesehatan Dan Ilmu Perilaku. Jakarta: Rineka Cipta.

Rahmita, Wahyuni S. (2013). Empati Mahasiswa Perokok Terhadap Orang Lain Di Sekitarnya Mengenai Paparan Secondhand Smoke Di Kampus Universitas Dian Nuswantoro Semarang [Skripsi]. Semarang:Universitas Dian Nuswantoro

Reda, A. A., Moges, A., Yazew, B., \& Biadgilign, S. (2012). Determinants of cigarette soking among school adolescents in eastern Ethiopia: a cross-sectional study. Harm reduction journal, 9, 39.

Robinson, S.,\& Lader, D. (2007). Smoking and Drinking Among Adults, 2007. Newport: Office for National Statistics Cardiff Rd.

Rudatsikira E, Abdo A, Muula AS. (2007). Prevalence and determinants of adolescent tobacco smoking in Addis Ababa, Ethiopia. BMC Public Health, 7,176.

Rudi, A., Masan, L., \& Kwureh, H.N. (2017). Efektifitas Peringatan Kesehatan Bergambar Bungkus Rokok Pada Pelajar. Wawasan Kesehatan, 4.

Sitepoe, M. (2000). Kekhususan Rokok Indonesia. Jakarta: PT Grasindo.

WHO. (2012). Global Adult Tobacco Survey: Indonesia Report 2011. New Delhi: WHO-SEARO 